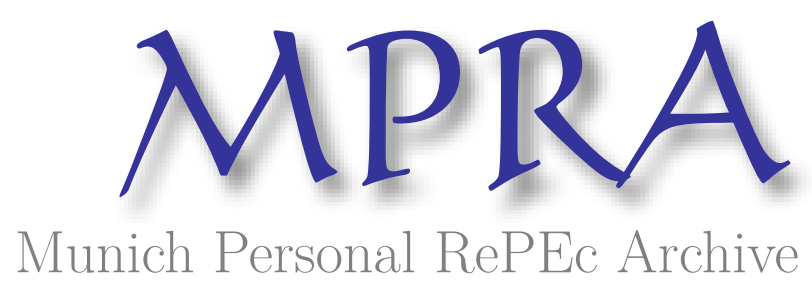

\title{
Innovation and Risk Management
}

Manuel, Eduardo

15 March 2007

Online at https://mpra.ub.uni-muenchen.de/2277/

MPRA Paper No. 2277, posted 16 Mar 2007 UTC 


\title{
INNOVATION AND RISK MANAGEMENT
}

\author{
EDUARDO G. MANUEL ${ }^{1}$
}

\begin{abstract}
Always, anytime, we speak about innovation, that it occurs in our live, firms, countries and regions.

The innovation is very important for survive of any firm, any entrepreneur, any country and any region in world market due to their speed evolution.

This paper has as objective to approach the relationship between Innovation and Risk Management.

We concluded that the relationship between innovation and risk management will exist always whereas we are continuing to live in global world that it originated a global market in all economic sectors. And for any firm, any entrepreneur, any country or any region that wants to survive in this world or market it need to do a risk management that consist in to innovate, and so can reduce the uncertainty relatively their contextual environment that affect a determined activity and consequently that is affecting their performance.
\end{abstract}

Keywords: Innovation, Risk, Risk Management

JEL Codes: D81, M19, M29, O31

Working Paper Series

\footnotetext{
${ }^{1}$ Eduardo Manuel has a B.A in Economics at University Autonoma of Lisbon (UAL), Portugal and it has a Master's Degree in Management of Enterprises at same University. He is the author of the book titled "Entrepreneurship, Economics and Competitiveness".

Eduardo Manuel is Economist, Investigator and Editor. e-mail address: edu.manuel@economista.com_or eduardo_manuel@mail.pt
} 


\section{INTRODUCTION}

Always, anytime, we speak about innovation, that it occurs in our live, firms, countries and regions.

The innovation is very important for survive of any firm, any entrepreneur, any country and any region in world market due to their speed evolution.

We know that all activities at entrepreneurial level that we develop has subjacent what we call "risk". An entrepreneur when define their business area, the risk exist, because sometimes it is difficult to forecast the evolution of our activity in the industry where we would like to enter as partner or as competitor (firm). This means that this entrepreneur can win or lose in their industry or market where he is.

This paper has as objective to approach the relationship between Innovation and Risk Management.

This paper is divided in three points: the first point searches to explain what innovation is; the second point approach what risk management is; and the last point (point 3) explains the relationship between innovation and risk management.

\section{WHAT IS INNOVATION?}

According to Edquist (1997), technological innovations are regarded as the introduction into the economy of new knowledge or new combinations of existing knowledge. This means that innovations are looked upon mainly as the result of interactive learning processes. Through interactions in the economy different pieces of knowledge become combined in new ways or new knowledge is created and, sometimes, this result in new processes or products. Such interaction does not only take place in connection with $\mathrm{R} \& \mathrm{D}$, but also in relation to normal and everyday economic activities such as procurement, production and marketing. This interaction that we are talking about occurs within firms (between different individuals or departments), between firms and consumers, between different firms, or between firms and other organizations like public agencies. 
According to Fagerberg, Mowery et al (2005), an important distinction is normally made between invention and innovation. According to their authors, invention is the first occurrence of an idea for a new product or process, while innovation is the first attempt to carry it out into practice. Sometimes, invention and innovation are closely linked to the extent that it is hard to distinguish one form another (biotechnology for instance). In many cases there is a considerable time lag between the invention and innovation that reflects the difference requirements for working out ideas and implementing them. While invention can be carried out anywhere, for example in universities, the same we cannot to say the innovations, they occur mostly in firms, though they may also occur in other types of organizations, such as public hospitals. A firm to be able to turn an invention into an innovation, a firm normally needs to combine several different types of knowledge, capabilities, skills and resources (technical, human and financial). For instance, the firm may require production of knowledge, skills and facilities, market knowledge, a well-functioning distribution system, sufficient financial resources, etc, that follows that the role of innovation, i.e., the person or organizational unit responsible for combining the factors necessary (what the innovation theorist Joseph Schumpeter called the "entrepreneur",", as we can see in the Box 1.1), may be quite different from that of the inventor.

It should to refer that the invention and innovation is a continuous process. For instance, the mobile phones, computers, and cars, we already know that, are constantly to be improved due to the incorporation of a very large number of different invention and innovation, according to the business strategy defined by firms where they are made.

\footnotetext{
${ }^{2}$ The word entrepreneur is French and literally translated means "between-taker" or "go-between" (Hissich and Peters, 2002). According to Nafziger (2006), the entrepreneur can be viewed in at least four ways: (1) as the coordinator of other production resources - land, labour, and capital; (2) as the decision maker under uncertainty; (3) as the innovator; and (4) as the gap filler and input completer. For further information see HISSICH, Robert D. and PETERS, Michael P. (2002), Entrepreneurship, Fifth Edition, International Edition, New York and NAFZIGER, E. Wayne (2006), Economic Development, 4th edition, Cambridge University Press, Cambridge.
} 


\section{Box 1.1. The innovation theorist Joseph Schumpeter}

Joseph Schumpeter (1883-1950) was one of the most original social scientists of the twentieth century. He grew up in Vienna around the turn of the century, where he studied law and economics. For most of his life he worked as an academic, but he also tried his luck as politician, serving briefly as finance minister in the first post-World War I (socialist) government, and as banker (without much success). He became professor at the University of Bonn in 1925 and later at Harvard University in the USA (1932), where he stayed until his death. He published several books and papers in German early on, among these the Theory of Economic Development, published in 1911 and in a revised edition in English in 1934. Among his most well-known later works are Business Cycles in two volumes (from 1939), Capitalism, Socialism and Democracy (1943), and the posthumously published History of Economic Analysis (1954).

Very early he developed an original approach, focusing on the role of innovation in economic and social change. It was not sufficient, Schumpeter argued, to study the economy through static lenses, focusing on the distribution of given resources across different ends. Economic Development, in his view, had to be seen as a process of qualitative change, driven by innovation, taking place in historical time. As examples of innovation he mentioned new products, new methods of production, new sources of supply, the exploitation of new markets, and new ways to organize business. He defined innovation as "new combinations" of existing resources. This combinatory activity he labelled "the entrepreneurial function" (to be fulfilled by "entrepreneurs"), to which he attached much importance. One main reason for the important role played by entrepreneurs for successful innovation was the prevalence of inertia, or "resistance to new ways" as he phrased it, at all levels of society that entrepreneurs had to fight in order to succeed in their aims. In his early work, which is sometimes called "Schumpeter Mark I", Schumpeter focused mostly on individual entrepreneurs. But in later works he also emphasized the importance of innovation in large firms (so-called "Schumpeter Mark II"), and pointed to historically oriented, qualitative research (case studies) as the way forward for research in this area.

In his analysis of innovation diffusion, Schumpeter emphasized the tendency for innovations to "cluster" in certain industries and time periods (and the derived effects on growth) and the possible contribution of such "clustering" to the formation of business cycles and "long waves" in the world economy (Schumpeter 1939). The latter suggestion has been a constant source of controversy ever since. No less controversial, and perhaps even better known, is his inspired discussion of the institutional changes under capitalism (and its possible endogenous transformation into "socialism") in the book Capitalism, Socialism and Democracy (1943).

Source: Fagerberg, Mowery, et al, 2005, p.6. 


\section{RISK MANAGEMENT}

\subsection{Risk Management in historical perspective}

An awareness of risk and recognition of the need for risk management have always been at the heart of commercial activity (Essinger and Rosen, 1991). A realization of the inevitable gap between expectations and reality has always characterized commercial activity; particularly once merchants began to make hazardous journeys overseas in search of returns that were potentially much bigger than could be obtained through arduous labour at home. In The Merchant of Venice - the first great work of literature whose plot turns on the issues of risk and loss - Shylock, speaking of Antonio, says:

"His means are in suppositions: he hath an argosy bound to Tripolis, another to the Indies...he hath a third at Mexico, a fourth for England, and other ventures he hath, squandered abroad. But ships are but boards, sailors but men: there be land - rats and water-rats, land-thieves and water-thieves - I mean pirates and then there is the peril of waters, winds and rocks".

In this speech we can see the idea of risk as threats that may render apparently valuable assets worthless.

In The Merchant of Venice, Shakespeare makes no mention of marine insurance; perhaps because the entire plot of the play would not have worked had Antonio taken the trouble to obtain such a facility. Marine insurance - the first type of insurance to become prominent - was already well-developed by the fifteenth century, and might be said to constitute the first significant application of risk management techniques. Shakespeare, who merely wished to write a dramatic play, could afford to overlook the existence of risk management. (Essinger and Rosen, 1991). These authors consider that if we who want to minimize our risk management as a prime requirement of our business activity, and if technology can help us to implement risk management strategies more effectively, rapidly and inexpensively, so much the better. 


\subsection{Definition of Risk Management}

Before the define risk management, we are going to define risk. So, what is risk?

What risk is today is very much what risk has always been: a measure of the anticipated difference between expectations and reality, that exists because the future is unknown; no amount of precautions can ensure that a ship sent to a distant land (or even a neighbouring land) returns at all, let alone returns laden with gold.

Risk management might be defined as an effective method for minimizing the adverse effects of risk and maximizing the benefits of incurring the risk (Essinger and Rosen, 1991).

According to Culp (2002), risk management is the process by which organizations try to ensure that the risks to which they are exposed are the risks to which they think they are and need to be exposed to operate their primary business. This author considers too that risk management is the process by which firms identify their risks and then take any ex-ante or ex-post actions required to control deviations of actual risk exposures from predefined tolerances to those risks.

Risk management is a cyclical process that must be repeated regularly during the course of a project.

Risk management begins an analysis of risk. With the aid of risk analysis, insight into the risks within a project can be gained systematically and the (effects of the) measures used approach these risks can be evaluated.

For Well-Stam, Liedennar, et al (2004), Risk management can help to:

- Promote an uninterrupted progression of the activities within a project and, by implementing the appropriate measures, remove any interruptions as quickly as possible should they occur;

- Instil confidence in the project, in third parties, and in the project team itself;

- Support the decision-making process within a project. 
For Chapman and Ward (1997), the essential purpose of risk management is to improve project performance via systematic identification, appraisal and management of project-related risk

\section{THE RELATIONSHIP BETWEEN INNOVATION AND RISK MANAGEMENT}

We saw in the point's one and two the definition of innovation and risk management. In this point we are going to see the relationship between innovation and risk management.

In my pointy of view, we can speak in the relationship between innovation and risk management always we speak about innovation management in business world. For example, when a firm sells a specific product in their industry; here there is risk if this product result of an invention that never had appeared in the market and the result of sales will depend the utility of good that is being sold for customers, so, if the good or product is good for them, then it will have profits for firm or it will increase, and if the good or product is not good, certainly this firm will be some difficult to sell it, and if this firm sell only this product or if this product is unique that is incorporated in their core business, probably this firm will have negative results in their industry, and it will lost competitiveness for other firms. Here is justifiable a project of risk management, and if we remember, we saw in the point 2.2 that risk management can help to:

- Promote an uninterrupted progression of the activities within a project and, by implementing the appropriate measures, remove any interruptions as quickly as possible should they occur;

- Instil confidence in the project, in third parties, and in the project team itself;

- Support the decision-making process within a project (Well-Stam, Lindenaar, et al, 2004).

We can say too that the relationship between innovation and risk management can be seem, when the firms are doing project for promotion of innovation. In this time, these firms are minimizing and managing their risk, by fact that if it does not it, they can 
lost their position in the industry where are selling their product or service for other (s) firm (s). These projects can consist in promotion of innovation in organization areas such as financial, human resources, marketing and advertising, strategic planning, production, and customer services.

If we see again the box 1.1, it is visible that Schumpeter mentioned as examples of innovation new products, new methods of production, new sources of supply, the exploitation of new markets, and new ways to organize business, and that he defined innovation as "new combinations" of existing resources. For him, this combinatory activity he labelled "the entrepreneurial function" (to be fulfilled by "entrepreneurs"), to which he attached much importance. One main reason for the important role played by entrepreneurs for successful innovation was the prevalence of inertia, or "resistance to new ways" as he phrased it, at all levels of society that entrepreneurs had to fight in order to succeed in their aims.

Here it is present the risk when a firm organize their business through new products, new methods of production, new sources of supply, the exploitation of new markets, but it important to refer that when an entrepreneur is doing this in their business, he is occurring a risk, and their success will depend of absorption of their innovation by industry where he is. And when the firm or the entrepreneur is organizing their business through innovation is doing risk management to could be better ready to competitiveness in their market.

Also, this is applicable for a country or region. For example, a country or region to innovate is doing a risk management, so it can be ready to competitiveness that is coming from others countries or regions. And it this country or region is doing risk management, in now days, it needs to innovate.

According that all we have said, we can say that the innovation and risk management need to be linked.

If we consider the managing innovation as an uncertainty reduction process like Pearson (1991), this means that risk management through management of innovation is an uncertainty reduction process against the competition from an industry or market. This author refers to uncertainty about ends or focus, i.e., what the output from the activity, is aimed at or is likely to result, and uncertainty about means or approaches, i.e., how such and end point is likely to be arrived at. 


\section{CONCLUSIONS}

We saw the definition of innovation and risk. In the last point of this paper we saw the relationship between innovation and risk management.

We concluded that the relationship between innovation and risk management will exist always whereas we continue to live in global world that it originated a global market in all economic sectors. And for any firm, any entrepreneur, any country or any region that wants to survive in this world or market it need to do a risk management that consist in to innovate, and so can reduce the uncertainty relatively their contextual environmental that affect a determined activity and consequently that is affecting their performance. 


\section{BIBLIOGRAPHICAL REFERENCES}

ARCHIBUGI, Daniele and MICHIE, Jonathan (1997), Technology, Globalisation and Economic Performance, First Published, Cambridge University Press, Great Britain

ARCHIBUGI, Daniele, HOWELLS, Jeremy, et al (1999), Innovation Policy in a Global Economy, First Published, Cambridge University Press, United Kingdom

CASSIOLATO, José E., LASTRES, Helena M. M, et al. (2003), Systems of Innovation and Development - Evidence from Brazil, Edward Elgar, United Kingdom and United States

CHAPMAN, Chris and WARD, Stephen (1997), Project Risk Management Processes, Techniques and Insights, John Wiley \& Sons, Chichester

CULP, Christopher L. (2001), The Risk Management Process - Business Strategy and Tactics, John Wiley \& Sons, Inc, New York and Canada

CULP, Christopher L. (2002), The Art of Risk Management - Alternative Risk Transfer, Capital Structure, and the Convergence of Insurance and Capital Markets, John Wiley \& Sons, Inc, New York

EDQUIST, Charles (1997), Systems of Innovation - Technologies, Institutions and Organizations, First Published, Series Editor: John de la Mothe, Pinter, London and Washington

EDQUIST, Charles (2003), The Internet and Mobile Telecommunications System of Innovation - Developments in Equipment, Access and Content, Edward Elgar, United Kingdom and USA

ESSINGER, James and ROSEN, Joseph (1991), Using Technology for Risk Management, First published, Woodhead-Faulkner, England 
FAGERBERG, Jan, MOWERY, David C, et al (2005), The Oxford Handbook of Innovation, First Published, Oxford University Press, Oxford and New York

FREEMAN, C. (1987), Technology and Economic Performance: Lessons from Japan, Pinter, London

FREEMAN, C. and PEREZ, C. (1988), Structural crises of adjustment: business cycles and investment behavior. In G.Dosi, C. Freeman, R.Nelson, G. Silverberg and L. Soete (eds), Technical Change and Economic Theory, Pinter, London

HISSICH, Robert D. and PETERS, Michael P. (2002), Entrepreneurship, Fifth Edition, International Edition, New York

Human Development Report 1993, United Nations Development Programme (UNDP), Oxford University Press, New York and Oxford

LANÇA, Isabel Salavisa (2001), Mudança Tecnológica e Economia - Crescimento, Competitividade e Indústria em Portugal, First Published, Celta Editora, Oeiras, Portugal

LUNDVALL, Bengt - Ake (1992), National Systems of Innovation - Towards a theory of Innovation and Interactive Learning, Pinter Publishers, Canada and USA

MANUEL, Eduardo G. (2006a), Governance of Intellectual Property and Technology in G-8 Countries, available at http://ssrn.com/abstract $=899126$

MANUEL, Eduardo Gando (2006b), Economia do Conhecimento. Perspectivas das diferentes regiões do Mundo e Oportunidades de Benchmarking, Dissertation for obtention the Master's Degree in Management of Enterprises, University Autonoma of Lisbon (UAL), Portugal 
NAFZIGER, E. Wayne (2006), Economic Development, 4th edition, Cambridge University Press, Cambridge

NELSON, R. (ed.) (1993), National Innovation Systems. A Comparative Analysis, Oxford University Press, New York and Oxford

NORTH, Douglas C. (1994), Economic Performance trough time, American Economic Review No 84(3), June

OECD (1997), National Innovation Systems, Paris, available at http://www.oecd.org/dataoecd/35/56/2101733.pdf (15/12/2006)

PEARSON, Alan W. (1991), "Managing Innovation: an uncertainty reduction process", edited by Jane Henry and David Halker in Managing Innovation, First published, SAGE Publications, London and NewburyPark, pp.18-27

PORTER, M. (1990), The Competitive Advantage of Nations, Macmillan, Basingstoke, UK

Relatório de Desenvolvimento Humano 2003, Programa das Nações Unidas para o Desenvolvimento (PNUD)

Relatório de Desenvolvimento Humano 2004, Programa das Nações Unidas para o Desenvolvimento (PNUD)

ROSENBERG, N. and BIRDZELL, L. (1986), How the West Grew Rich, Basic Books, New York

SCHIENSTOCK, Gerd (2004), Embracing the Knowledge Economy - The Dynamic Transformation of the Finnish Innovation System, Edward Elgar, United Kingdom and United States

WELL-STAM, D van, LINDENAAR, F, et al (2004), Project Risk Management, First Edition, Kogan Page, Great Britain and United States 
WORLD ECONOMIC FORUM (2004), The Global Competitiveness Report 20042005, Edited by Michael E. Porter, Klaus Schwab, Xavier Sala-i-Martin and Augusto Lopez-Claros, Palgrave Macmillan, New York

WORLD ECONOMIC FORUM (2006), The Global Competitiveness Report 20062007, Edited by Michael E. Porter, Klaus Schwab, Xavier Sala-i-Martin and Augusto Lopez-Claros, Palgrave Macmillan, New York 